\title{
Logical Analysis against Superstitions: Józef M. Bocheński on the Social Role of Philosophy
}

\author{
Anna Brożek \\ (University of Warsaw, Faculty of Philosophy)
}

\section{Introductory Remarks ${ }^{1}$}

The writings of Józef M. Bocheński are full of bon mots and slogans. This is one of them:

(1) A philosopher analyzes, not moralizes. ${ }^{2}$

Bocheński was a theorist and a practitioner, as well as an apologist, of philosophical analysis. He was convinced that real progress in philosophy is possible only through the application of analytic methods to small problems.

Bocheński wrote elsewhere:

(2) Philosophy has a demonic task: to destroy [...] superstitions. ${ }^{3}$

Here, Bocheński reveals what social role may be played by philosophy in the contemporary world.

Bon mots and slogans, even if they are expressed by the same person, are often difficult to assemble into a coherent vision. This paper's aim is to show how

1 I would like to thank the Reviewers for their comments that helped me to improve this paper. A shortened, simplified Polish version of this paper was published in the journal Filozofuj!(6/2020).

2 J.M. Bocheński, Między logikq a wiarą. Rozmowa $z$ Janem Parysem [Between Logic and Faith: An Interview with Jan Parys], Montricher 1988, p. 98. Unless otherwise stated, all translations from Polish are my own.

3 Ibid., pp. 85-86. 
to combine statement (1) with statement (2), namely to determine in what sense philosophical analysis may serve as a weapon in the battle against superstitions.

In $\S 2$, the concept of analysis, logical analysis in particular, is characterized in the spirit of Bocheński. In $\$ 3$, the concept of superstition is defined and commented on. Taking Bocheński's definition as the point of departure, some essential distinctions involved in this concept are explained. Then, in $\$ \$ 4-7$, some examples of Bocheński's "destruction of superstitions" are presented. It turns out that they are good examples of working against irrational attitudes by means of logical analysis.

Bocheński's fight against superstitions is a part of his contribution to the programme of anti-irrationalism, proposed and realized by the Lvov-Warsaw School (hereafter: LWS), the Polish (or more broadly: the Central-European) branch of analytic philosophy. Bocheński was not a typical member of the LWS as he did not undergo his academic education under the supervision of Kazimierz Twardowski or any of his students. However, one of Bocheński’s gymnasium teachers was Zygmunt Zawirski, an early student of Twardowski. Later, in the 1930s, Bocheński intellectually approached Jan Łukasiewicz and his community of Warsaw logicians. In 1936, together with Jan Salamucha and Jan Drewnowski, and with Łukasiewicz's support, they created the so-called Cracow Circle, a group concentrated on reforming Catholic theology by means of formal logic - according to the "syllogism" that since logic is a tool of philosophy, and philosophy, as medieval people used to say, is the ancilla (handmaid) of theology, then logic should be a tool of theology. ${ }^{4}$ This rather informal and unfortunately short-lived group (it became one more victim of the Second World War) was sometimes considered a branch of the LWS. Even though the contact between Bocheński and the "full" members of the LWS was not institutionalized, Bocheński was deeply touched by the programme and spirit of the School. This is clear not only in his Formale Logik, which carries out Łukasiewicz's programme of research in logic in its methodology and history, but even more in Bocheński's general anti-irrationalistic attitude, his drive for clarity of speech and strictness of argumentation, and his emphasis on independent thought. These ideals were implanted in all members of the LWS and form a kind of hallmark of the School.

Ibid., p. 85 . 


\section{What Is Analysis in General and Philosophical Analysis in Particular?}

Sto zabobonów. Krótki filozoficzny słownik zabobonów [One Hundred Superstitions: A Brief Philosophical Dictionary of Superstitions] was written by Bocheński with great "moralizing" passion. ${ }^{5}$ Bocheński not only analyzes superstitions but also condemns them, and sometimes even makes fun of them. This "moralizing" layer of his dictionary does not interest me here. Therefore, it is worth recalling a few details about the "purely" analytical method that was applied by Bocheński in other works. It should be emphasized that the question of the methods applied in philosophy was very important to him. ${ }^{6}$

To analyze a certain object is to distinguish, with cognitive aims, its components, or properties. We analyze when we seek to answer questions such as "What is it like?," "What are its components?", or "How does it work?" Analysis is a procedure applied in many disciplines, ranging from formal ones (see, for instance, mathematical analysis), through the natural sciences (see, for instance, chemical analysis), to the humanities (see, for instance, literary analysis or musical analysis). One may analyze various kinds of objects, including real, that is, spatio-temporal, objects (for instance, a sample of blood, certain chemical compounds), as well as unreal objects (for instance, mathematical functions, musical compositions taken as composers' ideas).

The choice of analytic methods, namely the procedures that are applied in order to analyze something, is determined by many factors, including the type of object analyzed and the instruments in use. We have direct access to real objects, but we have only indirect access to unreal objects. In a given real thing, for instance, in a given clock, we may manually distinguish its parts, but the components of some non-real objects, for instance the plot of a novel, we may distinguish only mentally. In some kinds of analysis, one needs to use real instruments (for instance, a hammer, a screwdriver, measuring instruments). However, more or less sophisticated conceptual instruments are needed in all kinds of analysis since every analysis is preceded by some theoretical background. Let

J.M. Bocheński, Sto zabobonów. Krótki filozoficzny słownik zabobonów [One Hundred Superstitions: A Brief Philosophical Dictionary of Superstitions], Warszawa 1988.

6 A sketch of Bocheński's views in the domain of the methodology of philosophy may be found in A. Brożek et al., Anti-Irrationalism: Philosophical Methods in the Lvov-Warsaw School, forthcoming. 
us add that the kinds of elements distinguished in the process of analysis are to a certain degree determined by this theoretical background. A given conceptual scheme indicates the intentional limits of the analysis. For instance, in a given sample imported from Mars, a chemist expects to find elements known from the periodic table. In a piece of music, we usually focus on elements such as tones, motifs, phrases, etc., the kinds of which are established within music theory. It happens, however, that the analyzed objects surprise us and force us to change our initial analytic hypotheses. The sample from Mars may theoretically contain unexpected, unknown elements, and musical compositions may extend the existing analytic schemes.

Philosophers also apply analysis, and not only in the tradition called "analytic philosophy." What is the object of philosophical analysis? Bocheński would probably say that philosophers analyze, first of all, concepts and their systems (conceptual schemes) as well as statements and their systems (theories). A philosopher's aim may be to indicate the components of one concept, to distinguish between two or more concepts or to construct an entire scheme of concepts related to one another. A philosopher may focus on one statement, or sequences of statements (which, for instance, express an argument or reasoning), as well as theories as wholes.

There are various conceptions of what concepts and statements are, how to cognize them, and what kinds of parts or properties could be distinguished in them. Some philosophers are convinced that it is possible to access concepts or statements, or even their "essences," directly. Bocheński's opinion, typical of analytic philosophers, was that the only way to gain access to concepts and statements is via language. Languages are their only intersubjectively accessible carriers. Simplifying, and very roughly speaking, one may say that concepts are (or may be represented as) the meanings of words, and statements are (or may be represented as) the meanings of sentences. Thus, words and sentences (belonging to natural, scientific, or philosophical languages) are the "empirical basis" of philosophical analysis and, at the same time, they serve as a tool which enables us to present the results of analysis. If the results of analysis of concepts and statements are to be expressed, they have to be expressed in a language.

It is obvious that languages, first of all natural languages and the informal languages of the sciences (that is, languages of various disciplines that are not formalized), provide a broad and rich corpus of empirical data, which is, at the 
same time, very difficult to process. It is almost never the case that one word is assigned to one concept and one sentence to one statement. In "living" languages, one regularly encounters vague, ambiguous expressions or evolving, fluctuating senses. When one applies analysis to such empirical data, one has to distinguish between and clarify the meanings of words, as well as pick apart and disambiguate the meanings of sentences. Such "corrections" are necessary if we want philosophical language to fulfil the elementary postulates of precision. Thus, due to these imperfections of concepts and statements, philosophical analysis is often combined with corrections or even with the construction of new concepts or conceptual schemes, new statements or new theories. The need for these (re)constructive elements is natural but is not always accepted by practitioners of analysis. In particular, there are currents in analytic philosophy which recommended only the use of natural languages in philosophy, with all of their imperfections. For Bocheński, as for all members of the LWS, philosophical language has to be as precise as possible - so, we cannot operate only in the area of natural languages.

Now, the question arises as to what tools may be used by a philosopher to make these conceptual distinctions or clarify the meanings of sentences. Bocheński belongs to the philosophical tradition in which one looks for the theoretical background of analysis in logic, broadly understood as encompassing theories of formal systems, logical semiotics, and methodology.

Mathematical logic gave philosophical investigations a serious impulse to develop. The most sophisticated way of using formal tools in philosophy consists in the axiomatization of some philosophical theories (or their parts). This procedure equips these theories with a mature form in which axioms and primitive terms are listed, all secondary terms are defined, and all theses are inferred from axioms. Some concepts can be defined, and, finally, inferential steps may be justified in a way that does not raise any doubts. Formal languages may also be used to indicate the logical forms of sentences and make clear the logical relations between sentences, thus ensuring sound reasoning and argumentation.

However, axiomatization may be employed only at the final step of the development of a given theory (including philosophical theories). Before this tool is used, much pre-formal and pre-axiomatic work is required. Here, the elements of logical semiotics, such as the theory of the functions of names, the analysis of semiotic defects, and various kinds of sentence paraphrasing, may be applied. In 
the end, the results of analysis are given in definitions of terms that are carriers of concepts and logical paraphrases of sentences that are carriers of statements.

All procedures that make use of broadly understood logical matters are called "logical analysis."

\section{What Are Superstitions?}

In the introduction to One Hundred Superstitions, Bocheński admits to having deliberately used the term "zabobon" instead of the much less pejorative Polish word "przesąd." In English, there are also two terms of similar meaning: "prejudice" and "superstitions," but the emotional elements in the meanings of these terms are perhaps not as strong as in their Polish quasi-equivalents. In this text, as an English equivalent of "zabobon," I choose the English "superstition"; however, let us keep in mind that Bocheński emphasized his contemptuous attitude towards superstitions even by his choice of terminology. ${ }^{8}$

In fact, in One Hundred Superstitions, the author assumes, to some extent, the role of moralizer. Some distinctions are introduced vaguely, and some referenced standpoints are "sharpened" in order to show more easily their superstitious character. The more mainstream character of the book, which was written for a larger audience, justifies this style to some degree. Still, the book may serve as a source of examples of applying simple logical tools in philosophical analysis.

Bocheński introduces the following definition:

7 About Bocheński's conception of analysis, see also M. Lechniak, J.M. Bocheński's Method of Philosophical Analysis and Contemporary Applied Ontology, "Studies in East European Thought" 2013, Vol. 65, No. 1-2, pp. 17-26. The methodological peculiarities of the LWS have been recently characterized by M. Będkowski et al., Analysis - Paraphrase - Axiomatisation: Philosophical Methods in the Lvov-Warsaw School, in: Formal and Informal Methods in Philosophy, eds. M. Będkowski et al., Leiden 2020, pp. 56-74.

8 He commented on this as follows: "Someone would say that by using this vituperative term ["zabobon"] I offend the venerable principles of polite comradeship. For, in the world of philosophers it is customary to deal elegantly with even the worst idiocy. When one wiseacre states that there is no world, or that it exists only in his head; when the second wiseacre proves that I cannot be sure that I am sitting right now, and when the third tells us that we have no consciousness or feelings - it is said to be a 'view,' 'opinion,' 'philosophical theory' and it is taught venerably to students” - J.M. Bocheński, Sto zabobonów, op. cit., p. 8. 

to a high degree false but still (2) considered surely true. ${ }^{9}$

In the first step, I propose modifying two elements of this formula. Firstly, I am convinced that "statement" is a better genus for the definition of "superstition" than "belief." ${ }^{10}$ Secondly, I would exchange "obviously and to a high degree false" with simply "obviously false" as I do not know what "levels of truthfulness" could be (and unfortunately I cannot ask Bocheński what he had in mind when using this expression). That is why the point of departure should be the formula:

(4) A superstition is a statement which is obviously false and still accepted as true.

Formula (4) requires further and deeper comments. Here, I will limit myself to three such comments.

Firstly, it is assumed here that one should distinguish the truthfulness of statement $S$ from accepting $S$ as true (or, in other words, being convinced that $S$ ). Take the statement expressed in the sentence "Bocheński was a Pole" as an example. Let us agree that this statement is true even if there is someone who does not accept this statement or even rejects it. Let us now consider a set of someone's convictions, and let this be the set of Bocheński's convictions in 1920, assuming that these convictions may be represented as sentences. Well, it is easy to guess that in the set of sentences accepted by Bocheński in 1920 there were some true

Ibid., p. 7.

10 Dictionaries often provide definitions of "superstition" in which, like in Bocheński's book, the genus proximum is the term "belief" (cf., e.g., The New Penguin English Dictionary, ed. R. Allen, London 2001). However, the phrase "a belief in superstition(s)" or "to believe in superstition(s)" is in common use (cf., e.g., The Encyclopedia of Superstitions, ed. R. Webster, Woodbury, MN 2008, p. x). Now, if we substitute the term "superstition" with the definiendum of the definition of "superstition" as a belief in these phrases, we get: "superstition = a belief in a certain belief." Taking "statement" as the genus solves this problem. It is significant that, for example, in Maty słownik języka polskiego [Little Dictionary of the Polish Language], ed. E. Sobol, Warszawa 2020, "[człowiek] zabobonny," that is, "superstitious [person]," is defined as "[człowiek] wierzący w zabobony," that is, "[person] believing in superstitions," and "superstition" is defined as "a [certain] belief" (just like in the English dictionary cited above). Unfortunately, it often happens that dictionaries lack logical culture. Let me also note on the margin that introducing the distinction between the concept of "superstition" and the concept of "belief in superstition" makes it easier to separate the logical issues (of superstitions as statements) that interest me - from the psychological ones (of belief in superstition), which was mentioned by one of the reviewers of this paper, and which certainly belongs to an interesting but different research field. 
as well as some false sentences. However, only some of these false sentences are superstitions. Being false and being accepted are not sufficient conditions of being a superstition.

Definition (4) assumes, secondly, a distinction between falsity simpliciter and obvious falsity. Under the entry for "superstition," Bocheński explains what "obviously false" means by listing the following sources of obvious falsity:

(5) An obviously false statement is either meaningless or blatantly inconsistent with facts, or inconsistent with the laws of logic. ${ }^{11}$

Again, I cannot restrain myself from a little intervention in that list. In my opinion, if a statement is meaningless, it is not a statement sensu stricto, so it is neither true nor false. That is why I would limit "obvious falsehood" to Bocheński's other two examples: contradiction (inconsistency with the laws of logic) and blatant inconsistency with facts.

Thirdly, let it be noted that an obviously false statement is a superstition only as long as it is accepted by someone. Let us agree that in order to accept a statement (or reject it) in the proper sense, one has to understand it. So, the problems of superstitions do not concern mad or unintelligent people who are unable to understand language expressions. Bocheński emphasizes that some obviously false statements happen to be accepted by people who are brilliant... Sometimes even millions of such people can accept a certain obviously false statement. How can this be? Nobody would like to accept an obviously false statement. People seem not to want to accept a sentence they know to be obviously false. So, the problem is that these people, despite their brilliance and intelligence, do not see the obvious falsity of some of their convictions and are not aware of it.

Bocheński admitted that in his adolescence he himself had been a victim of many superstitions, which, however, he later condemned - he freed himself from them. This is what a rational person does: refutes false beliefs upon realizing their falsity. It is not always easy to part with a conviction which is "deeply" accepted or to which we are emotionally attached. Sometimes we need somebody to show us the obvious falsity of a statement we accept.

After these explanations, it is easy to see in what sense logical analysis serves to destroy superstitions. The analysis of a given statement or a given concept involved in a statement makes it easier to reveal that this statement is obviously

11 J.M. Bocheński, Sto zabobonów, op. cit., p. 115. 
false. And, for a rational person, recognizing a certain sentence as obviously false is a sufficient reason to refute that sentence, to get rid of a superstition. The social role of analytic philosophers becomes clear: they make people realize that some statements accepted by them are false and should be rejected. Bocheński emphatically calls this process of freeing oneself from superstitions "spiritual resurrection."

\section{Superstitions about Gibberish}

From the fact that superstitions are (meaningful) statements, it does not follow, of course, that "superstitious" statements cannot concern gibberish. It's no wonder that Bocheński gives examples of just such superstitious gibberish.

A relatively harmless kind of gibberish is uttering words which are completely devoid of sense (like "hocus-pocus"). According to Bocheński, what is more dangerous is the kind of gibberish that consists in uttering words which have meaning but which are connected in a way that does not form a meaningful sequence of words. This form of gibberish Bocheński calls "abuse of the meaning of words." He accuses some theologians and philosophers of applying it and presenting their "erudite gibberish" as "deep truths."

Whoever takes such "erudite gibberish" for a meaningful expression, is a victim of a superstition.

Whoever considers gibberish to be a means of communicating objective information is a victim of superstition. [...] Believing that it may be useful for anything in this field is a gross superstition. Therefore, also the belief that a philosopher can or even should use gibberish, is a superstition. [...] The use of words that have subjective meaning is a specific characteristic of humans (and probably, at least partly, of higher animals). Those who would like to replace objective, comprehensible, human speech with gibberish bring humans down to a level lower than that of monkeys and rhinoceroses, because even those beasts use more than gibberish. ${ }^{12}$

$12 \quad$ Ibid., pp. 24-25. 


\section{Superstitions Concerning Authority}

Let us now concentrate on some of Bocheński's analyses of superstitions included in the aforementioned book.

Bocheński's main work on authority is his monograph Was ist Authorität?, published in German in 1974 and later translated into French and Polish. ${ }^{13}$ Since Bocheński's analysis of superstitions refers to the content of this book, let me recall its main points. ${ }^{14}$

Bocheński's starting point consists in analyzing some expressions in which the term "authority" occurs. He takes some natural-language statements as well as some theoretical approaches. This empirical material appears to be a real tangle of meanings. Even the category of authority is not easy to establish as it happens that authority is considered to be individual (someone is an authority), a property (someone has authority) or a relation (someone is an authority for someone else). This proves that some reordering is needed; the concept of authority requires a reconstruction. Bocheński decides that authority is basically a relation and, moreover, is convinced that it is a ternary relation between a certain object, a certain subject, and a certain domain. Objects and subjects of authority are conscious human beings, while the domain of authority may be represented as a set of sentences.

Bocheński notes that when one calls someone an authority (without any additions) or even when one says that person $A$ is an authority over person $B$ (without any additions), there is something missing in such a statement: it is elliptical. The concept of authority is entangled in a ternary relation and when speaking about authority, one has to recognize who the authority is, for whom, and in what domain. For instance, chemistry teachers are authorities for their students in the domain of chemistry (but not, for example, in the domain of the history of literature).

This simple observation helps us get rid of many superstitions. Bocheński writes:

13 In English, Bocheński published a shortened paper (J.M. Bocheński, An Analysis of Authority, in: Authority, ed. F.J. Adelmann, The Hague 1974, pp. 56-85).

14 Detailed reconstructions of the concepts of deontic authority and epistemic authority may be found in A. Brożek, Bocheński on Authority, "Studies in East European Thought" 2013, Vol. 65, No. 1-2, pp. 115-133. 
[One of the superstitions] connected with authority is the conviction that there are, so to speak, universal authorities, that is, people who are authorities in all domains. This is obviously not the case; each person is only an authority in a definite discipline. [...] Unfortunately, accepting such universal authorities is a very widespread superstition. When, for instance, a group of university professors signs a political manifesto it is assumed that the readers of such a manifesto would consider them authorities in the domain of politics, which they obviously are not [...]. For these professors are surely authorities in the domains of [the history of] the French revolution, Chinese ceramics, or probability calculus but not in the domain of politics, and by signing such a manifesto they abuse their authority. ${ }^{15}$

Now, even more than in Bocheński's times, we are often induced to believe that famous scholars or actors are authorities in the domain of morality or politics. A famous scholar or a famous actor, he argues, is certainly an authority in the domain of physics or acting, respectively, but they do not automatically become specialists in the current political situation, and they are not necessarily good advisers regarding our ethical choices. Let us repeat: there are no universal authorities and those who believe in them are just allowing themselves to be manipulated by false authorities.

Bocheński's most famous contribution to the theory of authority is his clear distinction between epistemic and deontic authority. In the case of epistemic authority, that is, the authority of an expert, the domain of authority is a set of "theoretical" sentences. Assume that $A$ and $B$ are humans and $D$ is a set of sentences. Now, we may define "epistemic authority" as follows:

(6) $A$ is an epistemic authority for $B$ in domain $D$, iff $B$ accepts, in principle, as true every sentence which was communicated to $B$ in the affirmative by $A$ and which belongs to domain $D$.

Deontic authority is the authority of a boss. The domain of this kind of authority is a set of orders. In particular:

(7) $A$ is a deontic authority for $B$ in domain $D$, iff there is an event $E$ such that (1) $B$ desires $E$ to be realized and (2) $B$ is convinced that $B$ 's

15 J.M. Bocheński, Sto zabobonów, op. cit., p. 21. 
execution of all orders given by $A$ with emphasis, and belonging to domain $D$, is a necessary condition for the realization of $E$.

Bocheński emphasizes that these two kinds of authority should not be confused and whoever takes a deontic authority for an epistemic one or vice versa is engaged with a superstition. It may happen that our bosses are also experts but it is not always the case. Bocheński comments that:

Lots of people believe that the one who has power, and thus is a deontic authority, is at the same time an epistemic authority, who can instruct his subjects, for instance in astronomy. [...] Outstanding people are also victims of this superstition, for instance Ignatius of Loyola, the founder of the Jesuit Order, in a famous letter to the Portuguese Fathers demanded that they "submit their reason to their superior," that is, to a purely deontic authority. ${ }^{16}$

These two superstitions have been described in order to protect us from the overuse of authority: we should be careful in accepting someone as an authority, we should not follow "false authorities," and we should clearly distinguish experts from bosses. Of course, reliance on authorities should be accompanied by cognitive caution. However, the next warning regarding superstition prevents us from refuting all authorities. Bocheński observes that we live in an era of a fast development of science and specialization. No one is able to grasp all domains of all disciplines. This is, as Bocheński would say, simply a fact. This is why we are doomed to depend on epistemic authority. The same concerns deontic authorities. There are situations in which it is reasonable to follow someone else's instructions. Consider the radical example of a sinking ship on which it is reasonable to follow the orders of the captain. Thus, Bocheński argues, refuting all authorities is simply contradictory to facts, and thus it is a superstition that it could be done.

To follow an authority is often a very rational attitude, in accordance with reason. When, for instance, a mother tells her child that there is a great city called "Warsaw," then the child is quite rational in accepting this as truth. Similarly, a pilot acts reasonably when he follows the instructions of a meteorologist who states that there is high air pressure in Warsaw and wind from the west [...] since there is information in both cases beyond the knowledge of the child or the pilot, respectively. We also use authority in science. In order to believe

16 Ibid., pp. 21-22. 
this, it is enough to look at the huge libraries of any scientific institute. Books in these libraries contain the reports of the results of other sciences, so they are statements of epistemic authority. ${ }^{17}$

Thus, the statement that there is always and everywhere a contradiction between authority and reason is, so to speak, a meta-superstition.

\section{Superstitions Connected with Patriotism}

The next example of superstitions relates to the concept of patriotism. The term "patriotism" in ordinary language causes similar problems to the term "authority." It is used with different, fluctuating meanings. Moreover, it is often the case that the participants of politics or social discussions manipulate these meanings. The only solution is, again, to introduce some conceptual ordering.

Bocheński's terminological adjustment may be expressed in the following definition:

(8) $A$ is a patriot, iff $A$ loves $A$ 's country and $A$ 's countrymen. ${ }^{18}$

Thus understood, patriotism is, as Bocheński emphasizes, "not a superstition but a virtue."

The question arises of how to operationalize the love of one's country and countrymen. Some of Bocheński's comments suggest that to love your country and your countrymen means at least to want what is good for them.

Now, the first superstition connected with patriotism is to confuse it with nationalism. In order to see the source of this confusion, we need a definition of "nationalism." The following formula reflects Bocheński’s intentions concerning this term:

(9) $A$ is a nationalist, iff $A$ adores/idolizes $A$ 's nation and hates other nations.

Once the definitions are established, the source of superstition becomes clear. Based on these assumptions, it is obvious that from the sentence in the form

\footnotetext{
${ }_{17}$ See ibid., p. 21. In reconstructions of Bocheński’s definitions or quasi-definitions I omit quantifiers.

18 Ibid., p. 81.
} 
" $A$ is a patriot" the sentence " $A$ is a nationalist" does not follow. Firstly, "idolizing" is something more than loving (let us set aside the question of how to operationalize these predicates). Secondly, from the fact that $A$ loves object $X$, it does not follow that $A$ does not love object $Y$. Thus, one who conflates patriotism and nationalism is guilty of a superstition.

The confusion of patriotism and nationalism has two sides, that is, it leads to two kinds of irrational attitudes. On the one hand, those patriots who become nationalists fall victim to a superstition. On the other hand, those who condemn patriotism because they unconsciously transform it into nationalism are also victims of superstition. According to Bocheński, the second superstition is more widespread and more dangerous.

[This means] that whoever loves their country more than, for instance, Ecuador or Vietnam is accused of racism. Moreover, if someone faced with a choice gives priority to their own countrymen over foreigners, that person is considered a racist criminal, like a Hitlerite. ${ }^{19}$

According to Bocheński:

Every human being has the right to take care of, first of all, people that are related to them, and without any thought about the superiority of this or that race. ${ }^{20}$

\section{Superstitions Related to the Concept of Tolerance}

Bocheński characterizes tolerance as "[the act of] enduring" ["znoszenie"]. This requires some clarification. Let us take the following formula as the point of departure:

(10) $A$ tolerates action $X$ iff $A$ endures action $X$.

I guess that Bocheński would agree that this formula may serve as the most basic explication of what tolerance is. He wrote that "we call a person 'tolerant' if they endure others, their views, their style of life." ${ }^{21}$

\footnotetext{
19 Ibid.

20 Ibid.

21 Ibid., p. 109.
} 
The concept of enduring requires further analysis. Let me only state shortly that it seems that the meaning of "enduring" may have two sides: behavioural and emotional. To endure something means not to act against it or to have at least a neutral emotional attitude towards it (not to condemn it).

(11) $A$ tolerates action $X$ iff $A$ does not act against action $X$.

(12) $A$ tolerates action $X$ iff $A$ does not condemn action $X$.

Let us emphasize this firmly: to endure a certain action does not mean to support this action or to affirm this action. Today, perhaps more than in Bocheński's times, we are asked to support or affirm some behaviours in the name of tolerance. Such requirements surely go beyond simple enduring.

Now, a tolerant person is a person who tolerates the actions of other people. A question arises: which actions? All of them or only the majority? It seems that tolerance is a gradable property. In such a situation, we may only define maximal or relative tolerance. These concepts, in their simplest versions, may be defined as follows:

(13) $A$ is maximally tolerant iff $A$ tolerates all actions.

(14) $A$ is more tolerant than $B$ iff $A$ tolerates more actions than $B$.

The principle of tolerance is connected with the concepts of tolerance and tolerant people. Superstitions arise precisely when it comes to this principle. What should it state? Bocheński emphasizes that generally tolerance is "a good way for various groups within one society, which differ with respect to worldviews or basic political theses, to coexist." 22 However, accepting the postulate of tolerance without any limitations is also a superstition. The postulate:

(15) Everyone should be maximally tolerant. / Every action should be tolerated.

should not be accepted by a rational person.

Suppose that action $X_{1}$ consists in offending us or our relatives. The postulate of maximal tolerance would require us not to act against such an offence (let as leave aside the emotional interpretation of tolerance as less important here).

22 Ibid. 
According to Bocheński, such actions, actions of violence, should obviously be excluded from the domain of the principle of tolerance.

The second example concerns political life. Suppose that action $X_{2}$ consists in the removal of the principle of tolerance from the regulations of a given country. In the name of the principle of tolerance, should we tolerate such attempts? According to Bocheński, obviously not. He states:

Then there are two superstitions: no tolerance entitles anyone to offend others, and a tolerance that tolerates its own enemies cannot stand. ${ }^{23}$

The statement that the principle of tolerance should not have any limitations is a superstition.

Bocheński drew attention to one more superstition connected with tolerance, the consequence of which is the destruction of the world of scholarly activities. According to the principle of tolerance (and, let us add, the principle of freedom of thought), no beliefs are prohibited. However, it is not the case that in the name of tolerance every kind of research has an equal right to be institutionally or financially supported. Bocheński's example is the following:

If there were someone defending the system of Ptolemy, then in tolerant countries this would not be prohibited. However, most likely such a person could not find an institute of astronomy that would finance such "research."24

Bocheński is aware that revolutions in science take place when some essentially new theories are discovered. However, generally speaking, tolerance in science should be limited in cases where the standards of scientific methods are abused.

\section{Closing Remarks}

Let us recapitulate the main points of the paper.

Bocheński believed that destroying superstitions, that is, obviously false but accepted statements, is one of the practical tasks of philosophers. From the methodological point of view, he was an analytic philosopher; therefore, he made use of the logical tools of formal logic, logical semiotics, and methodology in

$\begin{array}{ll}23 & \text { Ibid. } \\ 24 & \text { Ibid. }\end{array}$ 
order to analyze concepts and their schemes, statements, or whole theories. By distinguishing between and clarifying the senses of terms and providing logical paraphrases of sentences, one may demonstrate the obvious falsity of a given statement. For a rational human being, to see the obvious falsity of a statement is a sufficient condition for rejecting this statement, for parting with a superstition.

Bocheński's One Hundred Superstitions contains simplified analyses of some superstitions encountered in contemporary societies. As one may see based on the reconstructed examples (authority, patriotism, tolerance), the logical tools used by Bocheński are quite simple. Usually, he limits himself to definitions that clarify the meanings of words, or he disambiguates sentences by providing a quantifier. Still, these simple tools serve to make the reader realize the "superstitiousness" of some widespread statements.

By means of his programme of freeing people from superstitions, Bocheński joined the more general programme of anti-irrationalism realized in the LWS. Certainly, Bocheński was the kind of person described by Łukasiewicz:

It is as if the scales fall from the eyes of whoever has educated themselves in the exact thinking of mathematical logic. They see differences where others do not, and they see nonsense where others look for some mysterious depth. ${ }^{25}$

\section{Bibliography}

Będkowski M., Brożek A., Chybińska A., Ivanyk S., Traczykowski D., Analysis - Paraphrase - Axiomatisation: Philosophical Methods in the Lvov-Warsaw School, in: Formal and Informal Methods in Philosophy, eds. M. Będkowski, A. Brożek, A. Chybińska, S. Ivanyk, D. Traczykowski, Leiden 2020, pp. 56-74. Bocheński J.M., An Analysis of Authority, in: Authority, ed. F.J. Adelmann, The Hague 1974, pp. 56-85.

Bocheński J.M., Między logika a wiara. Rozmowa z Janem Parysem [Between Logic and Faith: An Interview with Jan Parys], Montricher 1988.

25 J. Łukasiewicz, O znaczeniu i potrzebach logiki matematycznej (1929) [On the Importance and Needs of Mathematical Logic], in: J. Łukasiewicz, Logika i metafizyka [Logic and Metaphysics], ed. J.J. Jadacki, Warszawa 1998, p. 431. 
Bocheński J.M., Sto zabobonów. Krótki filozoficzny słownik zabobonów [One Hundred Superstitions: A Brief Philosophical Dictionary of Superstitions], Warszawa 1988.

Bocheński J.M., Was ist Autorität? Einführung in die Logik der Autorität, Freiburg im Breisgau 1974 [French ed.: Qu'est-ce que l'autorité? Introducion à la logique de l'autorité, Fribourg 1979; Polish ed.: Co to jest autorytet?, in: Logika i filozofia. Wybór pism [Logic and Philosophy: Selection of Works], Warszawa 1993, pp. 187-324].

Brożek A., Bocheński on Authority, "Studies in East European Thought" 2013, Vol. 65, No. 1-2, pp. 115-133, https://doi.org/10.1007/s11212-013-9175-9.

Brożek A., Będkowski M., Chybińska A., Ivanyk S., Traczykowski D., Anti-Irrationalism: Philosophical Methods in the Lvov-Warsaw School, forthcoming. The Encyclopedia of Superstitions, ed. R. Webster, Woodbury, MN 2008.

Lechniak M., J.M. Bocheński's Method of Philosophical Analysis and Contemporary Applied Ontology, "Studies in East European Thought" 2013, Vol. 65, No. 1-2, pp. 17-26.

Łukasiewicz J., O znaczeniu i potrzebach logiki matematycznej (1929) [On the Importance and Needs of Mathematical Logic], in: J. Łukasiewicz, Logika i metafizyka [Logic and Metaphysics], ed. J.J. Jadacki, Warszawa 1998, pp. 424-436. Mały słownik jezyka polskiego [Little Dictionary of the Polish Language], ed. E. Sobol, Warszawa 2020.

The New Penguin English Dictionary, ed. R. Allen, London 2001.

\section{Summary}

According to Józef M. Bocheński, philosophers should analyze and not moralize. Bocheński also wrote that the philosophers' aim is to battle with superstitions. The present paper concerns the question of how philosophical analysis may serve this aim. In the first part of the paper, the kinds and tools of philosophical analysis are presented. In particular, the objects of philosophical analysis (concepts and statements) as well as logical "instruments" of analysis are discussed. In the second part, the concept of superstition (or prejudice) is analyzed. Taking Bocheński's definition as the point of departure, some essential distinctions in- 
volved in this concept are explained, for instance the distinction between truthfulness of a statement and somebody's acceptance of a statement, and the distinction between a false statement and an obviously false statement. Next, the mechanism of fighting against superstitions by means of analysis is shown using examples taken from Bocheński's book Sto zabobonów [One Hundred Superstitions] (1987). Superstitions connected with authority, patriotism, and tolerance are analyzed.

Key words: authority, logical analysis, patriotism, superstitions, tolerance 